\title{
Festival services: A study of visitors' experiences at surajkund craft fair
}

\author{
Sandeep Malik ${ }^{1, *}$, Manisha $^{2}$ \\ ${ }^{\mathbf{1}}$ Assistant Professor, ${ }^{2}$ Research Scholar, Institute of Hotel and Tourism Management, Maharshi Dayanand University, Rohtak, \\ Haryana, India
}

*Corresponding Author:

Email: smalik02@gmail.com

\begin{abstract}
More and more festivals are organized every year around the world, in big cities and villages alike, due to the numerous benefits they are perceived to bring at local and national levels. Past research show that fairs can bring positive benefits such as economic, social and community togetherness to their host community. In addition, fairs have the ability to create memorable experience for visitors, dampen negative images regarding host community, and create activities to motivate travelers. According to Getz (1991, 1997) festivals and public celebrations are seen as unique tourist attractions and destination image makers. Events and festivals also play a significant role in the lives of communities; enhance the local image of their host community (Getz, 1993). The experiences are base on the necessary services provided to the visitors. Therefore, the paper aims to examine visitor's experiences about various services of a famous fair i.e. Surajkund Craft Fair, Faridabad (Haryana). A structured Likert-type questionnaire was used to collect the opinions of respondents. The data was analysed using various appropriate statistical tool and the findings are presented in last part of the paper alongwith suggestions. This research clearly indicates that the Safety and Security services is major attribute of Services. Which highest 73.6 per cent visitors respond very good and lowest 1.3 per cent visitors respond very poor.
\end{abstract}

Keywords: Services, Craft Fair, Tourism, Visitors Experiences, Profile of Tourists.

\section{Introduction}

Fairs and festivals have become regular feature in recent years mainly because of main perceived benefits i.e. economical social to the host community. A part from this, these are formed to be complimenting the existing tourists activities, building positive image of the place and community and attracting new tourists. Highmore (2002) concluded that experience may have two stages; first 'moment by moment lived experience' and second, 'the evaluated experience'. Both of these are dependent on service quality, which is an important of business strategy. The service quality should be measurable and affective. Service is conjectural and the concept of service quality is even more abstract, making it very hard to quantify. Most recognized, in this context, is findings of Parasuraman, Zeithaml and Berry (1988) they asertained 5 dimensions of service quality i.e. Tangibles (appearance of physical facilities, personnel and materials), Reliability (dependable and accurate performance), Responsiveness (willingness to help customers and the promptness of service), Assurance (knowledge and courtesy of employees) and Empathy (caring and individualized attention to customers). One strategy that has been related to success is the delivery of high service quality, especially during times of intensive competition both domestically and internationally (Rao and Kelkar, 1997). This is true, particularly, for service industry like tourism where tourists enjoy the experience of product and don't own a product. In tourism industry, service quality can be used as a tool for competitive advantage in longterm. Tourism product have their own peculiar characteristics such as perishability, tangibility---etc. these unique features are also biggest limitation for the products necessaciating careful management of resources. As unsold services mean higher costs and lower profits. Fairs and festivals offer both products and services to visitors in the form of dance, music, art and craft exhibits, ethenical food items, paintings etc. these events are often cater to masses and are theme specific. Researcher have identified many socioeconomical benefits of these for destinations. Event(s) tourism was not widely used, if at all, prior to 1987 , events were not considered important for a destination. However, new Zealand tourist and publicity department (1987) recognized event tourism as a part of international tourism. Which is growing at a fast pace.

\section{Literature review}

SERVQUAL of Parasuraman Berry and Zeithaml and Parasuraman, Zeithaml and Berry $(1985,1988)$ is most famous and widely used tool for evaluating, service quality in case of service industry and its different sectors.

Getz (1991, 1997) described festivals and public celebrations as unique tourist attraction and helpful in destination marketing. Furthermore, these can contribute a lot in the living of host society and by strengthening the image of locals.

Khutson, Stevens, Patton \& Thomson (1992) used SERVQUAL and formulated LODGSERV to study service quality in lodging industry. The scale has five main dimensions i.e. reliability, assurance, responsiveness, tangibles, and empathy. Mei, Dean \& White (1999) described another scale, HOLSERV was developed again based on SERVQUAL to investigate 
service quality in hospitality industry. This scale has three dimensions relating to employees, tangibles, and reliability.

According to Lee, C-K., Lee, Y-K, Wicks, B. E. (2004) tourists visiting festivals have varied motivations, needs, and wants. Cultural festivals are more likely to attract more visitors then other festivals.

Since service quality is an elusive concept, there is still a debate on how best to conceptualize it and how service quality can be measured in different contexts. There is still a need to develop service quality measures that are country/industry-specific (Karatepe, Yavas, \& Babakus, 2005; Crick and Spencer, 2011). This is because service quality build that are processed particularly for one culture/industry may not be applicable in a different setting (Mattila, 1999; Hsieh and Tsai, 2009; Salazar, Xosta, \& Rita, 2010). George (2015) found that cultural festivals focusing on music, food and art represent significant community and economic opportunities for rural communities. The paper examined three South Australian festivals from multiple perspectives; first one is to recognize what relevant stakeholders consider festivals contribute to the society and how this may impact on the success of the festival itself. In this study he use Mitchell's model of creative destruction/creative enhancement as a theoretical framework and through qualitative analysis. Findings suggest that those communities who present a more complex understanding of the "rural idyll" through the integration of multiple local products will experience greater success, both for local and outsider audiences. Black (2016) demonstrated the networks of connections which festivals enable between the culture, heritage and people (individuals and groups) of a place. By focusing on four indicators his research showed the social impact of connections through the festival processes and content and argued that small-scale festivals in rural locations can contribute to social sustainability if they demonstrate a balance of both consistency and innovation and accessibility and openness within the locale.

\section{Objectives of Study}

In this research we have one objective

1. To study visitors' experiences about services of Surajkund craft fair.

2. To explore the impact of gender on use of mobile app of the fair.

3. To study the association of gender and complaint and grievance handling.

4. To examine the relationship of gender and ticketing facilities of the fair.

5. To investigate the association between gender and information services.

6. To inspect the relationship of gender of respondents and public convenience facilities.

\section{Research methodology}

The present study "Festival Services: A Study of Visitors' Experiences at Surajkund Craft Fair" is an exploratory in nature. The information was being collected through structured questionnaire from the Surajkund craft fair visitors. Sample size of visitors was 397 all the respondents responded seriously. Statistical Package for the Social Sciences (SPSS) version 19 was religiously used for the statistical analyses. Coding of variables in quantitative research is very critical for better interpretation of results. Age, education, occupation, place of origin, how do you reach fair, how many times to have visited the fair, from where did you get the information and what motivated you to come to Surajkund Craft fair were all coded and were entered in to the computer. The questions and responses were coded and entered in the computer using Microsoft Excel software. Required analysis was done with the aid of Statistical Package for Social Sciences 19 Version. 5 point Likert scale was used to know the responses of the respondents with the help of a structured questionnaire. The responses were measured in terms of very good, good, average, poor, and very poor.

\section{Data Analysis}

The results were draw on the responses collected from 397 visitors through self-administered questionnaires. The instrument had two sections; first part, had questions related to demographic profile of visitors; and second section, was used to collect information about experience of visitors regarding various services of Surajkund craft fair. Demographic profile of visitors was presented using frequency distribution tables; and percentage analysis was used to evaluate responses related to different services of the fair.

\section{Profile of Visitors}

397 visitors visiting Surajkund craft fair were contacted and their experiences were obtained with the help of structured questionnaire. The profile of visitors are presented in Table 1.

Sample characteristics were shown in Table no. 1 the sample size selected was 397. Male respondents were overrepresented by 67.8 per cent while female respondents were 32.2 per cent. Majority of the respondents were in the young age group of Less than 25 years ( 65.5 per cent), followed by 23.2 per cent of the sample were in age group of 26-35 years. Majority of the visitors i.e. 51.6 per cent were students and there were only 18.4 per cent professional. Almost half of the respondents has bachelor's degree (41.1 per cent), followed by master's degree (11.6 per cent). More than half of the respondents were local i.e. 58.9 per cent and 32.0 per cent from nearby districts whereas about 5.5 per cent of respondents were from other state. 
Table 1: Visitor Profile of the festival

\begin{tabular}{|c|c|c|c|c|}
\hline $\begin{array}{l}\text { Sr. } \\
\text { No. }\end{array}$ & & $\begin{array}{l}\text { Demographic } \\
\text { Variables }\end{array}$ & $\begin{array}{c}\text { Frequency } \\
(\mathrm{N}=397)\end{array}$ & Percent (\%) \\
\hline \multirow[t]{2}{*}{1} & \multirow[t]{2}{*}{ Gender } & Male & 269 & 67.8 \\
\hline & & Female & 128 & 32.2 \\
\hline \multirow[t]{5}{*}{2} & \multirow[t]{5}{*}{ Age } & Less than 25 years & 260 & 65.5 \\
\hline & & $26-35$ years & 92 & 23.2 \\
\hline & & $36-45$ years & 18 & 4.5 \\
\hline & & 46- 55 years & 18 & 4.5 \\
\hline & & Above 55 years & 9 & 2.3 \\
\hline \multirow[t]{3}{*}{3} & \multirow[t]{3}{*}{ Education } & $+2 / 12^{\text {th }}$ & 188 & 47.4 \\
\hline & & Graduate & 163 & 41.1 \\
\hline & & Post graduate & 46 & 11.6 \\
\hline \multirow[t]{4}{*}{4} & \multirow[t]{4}{*}{ Occupation } & Student & 205 & 51.6 \\
\hline & & Professional & 73 & 18.4 \\
\hline & & Business man & 34 & 8.6 \\
\hline & & Others & 85 & 21.4 \\
\hline \multirow[t]{5}{*}{5} & \multirow{5}{*}{ Place of origin } & Local & 234 & 58.9 \\
\hline & & Nearby districts & 127 & 32.0 \\
\hline & & Far of districts & 14 & 3.5 \\
\hline & & Other state & 22 & 5.5 \\
\hline & & Other country & 234 & 0.1 \\
\hline
\end{tabular}

The responses of respondents regarding nine dimensions of the festival services were gathered on a Likert type 6 point scale ranging from "Can't Say" to "Very Good", where "Can't Say" stands for " 0 " any "Very Good" represent "5". The finding are presented in Table No. 2.

It was revealed, in the first attribute, Cleanliness and Sanitation Services, that highest per cent i.e. 76.3 of visitors feels that the fair has quite high standards cleanliness and sanitation, however, only 0.5 per cent of visitors found it very poor.

The second attribute is realted to Parking Services available in the fair area for visitors, in which highest 67.8 per cent visitors responded very good and a marginal number i.e. 0.8 per cent visitors found this service Very Poor.

The service of providing food and beverage items to visitors, Food \& beverage outlets, was the third attribute. Majority of the visitors i.e. 63.7 per cent were very happy with the quality and number of food and beverage outlets operating in the fair area and responded Very Good, however, a meagre number of visitors (1.3 per cent) found these services Very Poor.

The next attribute, Safety and Security Services, was intended to know the opinions of respondents about the safety and security arrangements in the fair area. Most of the respondents i.e. around 95 per cent were of the view that there are adequate safety and security measures to ensure a feeling of safety and security among the visitors. But still, 1.3 per cent of visitors were not happy with these provisions.

Fifth attribute was aimed to identify the effectiveness of mobile app of the fair. It was revealed from the responses that around 69.5 per cent, i.e. highest number of visitors, found the app very effective and informative; whereas it appeared that fairly large number of visitors i.e. 25.2 per cent were not using the app.

Table 2: Responses to different Dimensions of Festival Services

\begin{tabular}{|l|c|c|c|c|c|c|c|}
\hline \multicolumn{2}{|l}{$\begin{array}{l}\text { Various Dimensions of Festival } \\
\text { Services }\end{array}$} & $\begin{array}{c}\text { Can't } \\
\text { say }\end{array}$ & $\begin{array}{c}\text { very } \\
\text { poor }\end{array}$ & poor & average & good & $\begin{array}{c}\text { very } \\
\text { good }\end{array}$ \\
\hline \multirow{2}{*}{$\begin{array}{l}\text { Cleanliness and Sanitation } \\
\text { Services }\end{array}$} & Frequency & 4 & 2 & 4 & 20 & 64 & 303 \\
\cline { 2 - 9 } & Percent & 1 & 0.5 & 1 & 5 & 16.1 & 76.3 \\
\hline Parking Services & Frequency & 17 & 3 & 4 & 15 & 89 & 269 \\
\cline { 2 - 9 } & Percent & 4.3 & 0.8 & 1 & 3.8 & 22.4 & 67.8 \\
\hline \multirow{2}{*}{$\begin{array}{l}\text { Food and Beverage } \\
\text { outlets }\end{array}$} & Frequency & 7 & 5 & 7 & 25 & 100 & 253 \\
\hline \multirow{2}{*}{$\begin{array}{l}\text { Safety and Security } \\
\text { services }\end{array}$} & Percent & 1.8 & 1.3 & 1.8 & 6.3 & 25.2 & 63.7 \\
\hline Mobile App. of the fair & Frequency & 4 & 5 & 0 & 13 & 83 & 292 \\
\cline { 2 - 9 } & Percent & 1 & 1.3 & 0 & 3.3 & 20.9 & 73.6 \\
\hline & Frequency & 100 & 3 & 4 & 14 & 93 & 183 \\
\hline Complaint/Grievance & Percent & 25.2 & 0.8 & 1 & 3.5 & 23.4 & 46.1 \\
\hline
\end{tabular}




\begin{tabular}{|l|c|c|c|c|c|c|c|}
\hline Handling & Percent & 20.2 & 1.5 & 0.8 & 5 & 21.2 & 51.4 \\
\hline $\begin{array}{l}\text { Ticketing of Fair and } \\
\text { Other recreational } \\
\text { Facilities }\end{array}$ & Frequency & 5 & 3 & 10 & 41 & 105 & 233 \\
\cline { 2 - 8 } & Percent & 1.3 & 0.8 & 2.5 & 10.3 & 26.4 & 58.7 \\
\hline Information Services & Frequency & 39 & 2 & 7 & 11 & 74 & 264 \\
\cline { 2 - 8 } & Percent & 9.8 & 0.5 & 1.8 & 2.8 & 18.6 & 66.5 \\
\hline \multirow{2}{*}{ Public Conveniences } & Frequency & 19 & 4 & 4 & 16 & 66 & 288 \\
\cline { 2 - 8 } & Percent & 4.8 & 1 & 1 & 4 & 16.6 & 72.5 \\
\hline
\end{tabular}

Next attribute was related to the Complaint/Grievance Handling. Almost half of the respondents i.e. 51.4 per cent revealed that the fair has a Very Good mechanism of dealing with complaint handling. One-fourth of the visitors responded in favour of Good option in the questionnaire and only 9 respondents were not happy with this service of the particular fair. Ticketing of Fair and other Recreational Facilities is the seventh criterion to judge the festival services of the fair. Nearly 60 per cent i.e. 58.7 per cent of visitors favoured the Very Good option whereas nearly 1 per cent $(0.8$ per cent) visitors opted for Very Poor response.

The attribute related to Information Services was the next criterion to evaluate the fair. 66.5 per cent and 18.6 per cent of visitors exhibited their strong agreement that the fair has Very Good and Good information services. However, around 10 per cent of visitors were of neutral opinion.

The last attribute was Public Conveniences which aimed at measuring the opinions of respondents about the state of public conveniences at the fair. In this, highest per cent of visitors 72.5 responded Very Good and lowest 1.0 per cent visitors responded Poor.

In the next step, Chi-Square test was applied to check the association of gender with various measures of festival services. The findings are presented in Table no.3. The results indicate that there is no statistically significant association between Gender and four of the festival service measures i.e. Cleanliness and Sanitation
Services, Parking Services, Food \& beverage outlets, Safety and Security Services; as the Pearson Chi-Square values are 4.730, 6.895, 5.050, and 4.273, respectively; and calculated significances are $0.450,0.229,0.410$, and 0.370 at 5 per cent level, respectively. Therefore, it can be induced that both males and females are satisfied with the hygiene and sanitation services; availability of parking services; variety and quality in food and beverage outlets; and safety and security arrangements at the festival ground.

Whereas, remaining dimensions of the festival services showed statistically significant association with the gender of respondents. The value of ChiSquare i.e. 11.182 is statistically significant, 0.048 , at 5 per cent level for use of mobile app of the fair for males and females respondents. It is also supported by the significant value of Phi and Cramer's V.

Gender was found to be marginally significantly affecting the respondents' opinions about complaint/grievance handling services at the festival; as the value of Chi-Square (11.054) is equal, 0.050, to the level of significance at 5 percent; and Phi and Cramer's $\mathrm{V}$ are significant.

There was a statistically significant relationship between gender and ticketing of the fair and other facilities available at the festival; as the Chi-Square value is 16.967 which is significant $(0.005)$ at 5 percent level of significance. It can be judged that the males and females don't have same opinions about ticketing of various facilities at the festival.

Table 3: Association of Gender with Various Aspects of Studied Measures

\begin{tabular}{|c|c|c|c|}
\hline & Value & df & $\begin{array}{c}\text { Asymp. Sig. } \\
\text { (2-sided) }\end{array}$ \\
\hline \multicolumn{4}{|l|}{ Cleanliness and Sanitation Services } \\
\hline Pearson Chi-Square & $4.730^{\mathrm{a}}$ & 5 & 0.450 \\
\hline Likelihood Ratio & 6.509 & 5 & 0.260 \\
\hline Linear-by-Linear Association & 0.104 & 1 & 0.748 \\
\hline Phi & 0.109 & - & 0.450 \\
\hline Cramer's V & 0.109 & - & 0.450 \\
\hline \multicolumn{4}{|l|}{ Parking Services } \\
\hline Pearson Chi-Square & $6.895^{\mathrm{a}}$ & 5 & 0.229 \\
\hline Likelihood Ratio & 9.416 & 5 & 0.094 \\
\hline Linear-by-Linear Association & 2.656 & 1 & 0.103 \\
\hline Phi & 0.132 & - & 0.229 \\
\hline Cramer's V & 0.132 & - & 0.229 \\
\hline
\end{tabular}




\begin{tabular}{|c|c|c|c|}
\hline \multicolumn{4}{|l|}{ Food and Beverage outlets } \\
\hline Pearson Chi-Square & $5.050^{\mathrm{a}}$ & 5 & 0.410 \\
\hline Likelihood Ratio & 6.877 & 5 & 0.230 \\
\hline Linear-by-Linear Association & 3.743 & 1 & 0.053 \\
\hline Phi & 0.113 & - & 0.410 \\
\hline Cramer's V & 0.113 & - & 0.410 \\
\hline \multicolumn{4}{|l|}{ Safety and Security services } \\
\hline Pearson Chi-Square & $4.273^{\mathrm{a}}$ & 4 & 0.370 \\
\hline Likelihood Ratio & 4.046 & 4 & 0.400 \\
\hline Linear-by-Linear Association & 1.415 & 1 & 0.234 \\
\hline Phi & 0.104 & - & 0.370 \\
\hline Cramer's V & 0.104 & - & 0.370 \\
\hline \multicolumn{4}{|l|}{ Mobile App. of the fair } \\
\hline Pearson Chi-Square & $11.182^{\mathrm{a}}$ & 5 & 0.048* \\
\hline Likelihood Ratio & 13.336 & 5 & 0.020 \\
\hline Linear-by-Linear Association & 7.037 & 1 & 0.008 \\
\hline Phi & 0.168 & - & 0.048 \\
\hline Cramer's V & 0.168 & - & 0.048 \\
\hline \multicolumn{4}{|l|}{ Complaint/Grievance Handling } \\
\hline Pearson Chi-Square & $11.054^{\mathrm{a}}$ & 5 & 0.050* \\
\hline Likelihood Ratio & 11.562 & 5 & 0.041 \\
\hline Linear-by-Linear Association & 0.834 & 1 & 0.361 \\
\hline Phi & 0.167 & - & 0.050 \\
\hline Cramer's V & 0.167 & - & 0.050 \\
\hline \multicolumn{4}{|l|}{$\begin{array}{l}\text { Ticketing of Fair and Other } \\
\text { recreational Facilities }\end{array}$} \\
\hline Pearson Chi-Square & $16.967^{\mathrm{a}}$ & 5 & $0.005 *$ \\
\hline Likelihood Ratio & 19.807 & 5 & 0.001 \\
\hline Linear-by-Linear Association & 5.923 & 1 & 0.015 \\
\hline Phi & 0.207 & - & 0.005 \\
\hline Cramer's V & 0.207 & - & 0.005 \\
\hline \multicolumn{4}{|l|}{ Information Services } \\
\hline Pearson Chi-Square & $15.059^{\mathrm{a}}$ & 5 & 0.010* \\
\hline Likelihood Ratio & 16.332 & 5 & 0.006 \\
\hline Linear-by-Linear Association & 2.636 & 1 & 0.104 \\
\hline Phi & 0.195 & - & 0.010 \\
\hline Cramer's V & 0.195 & - & 0.010 \\
\hline \multicolumn{4}{|l|}{ Public Conveniences } \\
\hline Pearson Chi-Square & $18.220^{\mathrm{a}}$ & 5 & 0.003* \\
\hline Likelihood Ratio & 19.108 & 5 & 0.002 \\
\hline Linear-by-Linear Association & 0.672 & 1 & 0.412 \\
\hline Phi & 0.214 & - & 0.003 \\
\hline Cramer's V & 0.214 & - & 0.003 \\
\hline
\end{tabular}

Information services at the studied festival were found to be dependent on the gender of the respondents. As the value of Chi-Square, 15.059, is statistically significant (0.010) at 5 per cent level of significance; which is well supported by value of Phi and Cramer's $\mathrm{V}$.
The opinions of male and female respondents varied significantly for public conveniences in the Surajkund Festival area. This is shown by the value of Chi-Square, 18.220 which is statistically significant $(0.003)$ at 5 per cent level of significance. These findings were corroborated by the Phi and Cramer's V. 


\section{Conclusion}

Events and Festivals have been recognized by various studies as an important motivator of tourism. By their nature, events and festivals are of short duration usually in a particular month or season and are based around a theme, large number of people around the world every year dedicate huge amounts of time and money to attend festivals. It is noted that these events and festivals are becoming big business in local communities and involve tremendous amounts of marketing and organization. Many retail businesses depend on them for their success, because when tourists attend events, they shop, eat and drink, which indirectly boost these retail businesses. There are various tools that measure and improve quality service as well as mechanisms for quality recognition in the tourism and hospitality industry. But as such, there is no state specific scale to measure service quality in the tourism sector in India or abroad. Events and festivals are mostly used to attract visitors or tourist to a destination to offer experiences that are unique to those that occur in everyday activities. SERVQUAL being introduced by Parsauraman et al. (1988) has been adopted widely across the world. Initially it was a 22 item scale which later was reduced to a 5-items scale with reliability, assurance, tangibility, empathy and responsiveness (Prasuraman et al., 1991). In this study we know about the visitors' experiences about the services of Surajkund craft fair. This research clearly indicates that the Safety and Security Services is major attribute of Services. Which highest 73.6 per cent visitors respond very good and lowest 1.3 per cent visitors respond very poor. Second attribute is Cleanliness and Sanitation Services in which highest 76.3 per cent visitors respond very good and lowest 0.7 per cent visitors respond very poor. There were statistically significant differences in the opinion of male and female respondents on aspects such as use of mobile app, complaint/grievance handling services, ticketing of the fair and other facilities, information services, and public conveniences. Whereas, other aspects of festival services are independent of gender in the study. The findings of the study are very helpful for policy planners and practitioners for working toward better visitors' satisfaction in festivals. However, every research has its own boundaries in terms of universe, sample size, area etc. So do this research has its own limitations, but still, it will serve as foundation for further research in the still unexplored area of visitors' satisfaction in festivals.

\section{References}

1. Black, N. (2016). Festival Connections. International Journal of Event and Festival Management.

2. Crick, A.P., \& Spencer, A. (2011). Hospitality quality: new directions and new challenges. International Journal of Contemporary Management, 23, 214-230.

3. George, J. (2015). Examining the cultural value of festivals. International Journal of Event and Festival
Management, Vol. 6 Iss 2 pp. 122 - 134

4. Getz, D. 1991. Festivals, Special Events, and Tourism. Van Nostrand, New York.

5. Getz, D. 1993. The planning for tourism business district. Annals of Tourism Research 20(3), 583-600.

6. Getz, D. 1997. Event Management \& Events Tourism. Cognizant Communications, New York.

7. Highmore, B. (2002). Everyday life and cultural theory. London: Routledge.

8. Hsieh, A., \& Tsai, C. (2009). Does national culture really matter? Hotel service perceptions by Taiwan and American tourists. International Journal of Culture, Tourism and Hospitality Research, 23(1), 54-69.

9. Karatepe, O.M., Yavas, U., \& Babakus, E. (2005). Measuring service quality of banks: scale development and validation. Journal of Retailing and Consumer Services, 12, 373-383.

10. Khutson, B., Stevens, P., Patton, M., \& Thomson, C. (1992). Consumers' expectations for service quality in economy, mid-priced and luxury hotels. Journal of Hospitality and Leisure Marketing, 1(2), 27-43.

11. Lee, C-K., Lee, Y-K, Wicks, B. E. (2004). Segmentation of festival motivation by nationality and satisfaction. Tourism Management 25(1), 61.70.?

12. Mattila, A.S. (1999). The role of culture in the service evaluation process. Journal of Service Research, 1(3), 250-261.

13. Mei, A.W.O., Dean, A.M., \& White, C.J. (1999). Analyzing service quality in the hospitality industry. Managing Service Quality, 9(2), 136-143.

14. New Zealand Tourist and Publicity Department. (1987). New Zealand tourism report no. 38 (November).

15. Parasuraman, A., L. L. Berry, and V. A. Zeithaml. (1985). A conceptual model of service quality and its implications for future research. Journal of Marketing 49 (4):41-50.

16. Parasuraman, A., V. A. Zeithaml, and L. L. Berry. (1988). servqual: A multiple-item scale for measuring consumer perceptions of service quality. Journal of Retailing 64 (1):14-40.

17. Rao, C.P. and Kelkar, M.M. (1997). Relative impact of performance and importance ratings on measurement of service quality. Journal of Professional Services Marketing, Vol. 15 No. 2, pp. 69-86.

18. Salazar, A., Xosta, J., \& Rita, P. (2010). A service quality evaluation scales for the hospitality sector: Dimensions, attributes and behavioural intentions. Worldwide Hospitality and Tourism Themes, 2(4), 46-57. 